\title{
MUDANÇAS NO PIBID E NA PREPARAÇÃO DE PROFESSORES PARA O INÍCIO DA DOCÊNCIA: ANÁLISE EM MULTINÍVEIS BASEADA NA THCA
}

\author{
LEANDRO DE OLIVEIRA RABELO ${ }^{1}$ \\ ORCID: https://orcid.org/ 0000-0002-2411-2459 \\ VALÉRIA SILVA DIAS ${ }^{2}$ \\ ORCID: https://orcid.org/ 0000-0002-8786-5642
}

FERNANDO LUIZ DE CAMPOS CARVALHO 3

ORCID: https://orcid.org/ 0000-0002-2752-1020

\begin{abstract}
RESUMO: Neste artigo analisamos algumas das recentes mudanças impostas ao Programa de Bolsa de Iniciação à Docência (PIBID) vigente no Brasil desde 2007. O Programa cumpriu, na última década, a importante tarefa de preparar melhor os licenciandos para o início da carreira docente; porém, o último edital lançado em 2018 modificou significativamente a estrutura do Programa, alterando seu potencial formativo. Com base na Teoria Histórico-Cultural da Atividade, analisamos parte das atividades desenvolvidas no âmbito de um subprojeto de Física do PIBID de uma universidade federal. A análise foi realizada em três níveis. No nível micro, analisamos as situações sociais de curta duração que potencializaram a preparação para o início da docência de licenciandos do subprojeto. No nível meso, analisamos o sistema de atividade desse subprojeto, evidenciando os elementos que mais contribuíram e quais se mostraram limitados na formação dos futuros professores. No nível macro, investigamos como as mudanças no PIBID, acompanhadas pelo lançamento do Programa de Residência Pedagógica, afetaram o sistema de atividades do PIBID. Nossos resultados indicam que essas mudanças podem provocar o distanciamento do PIBID de sua identificação com a iniciação à docência, pois prejudicam a eficiência da ação de tutoria, diminuem a heterogeneidade dos sujeitos que compõem os subprojetos e enfraquecem as parcerias entre universidades e escolas. Além disso, não contribuem para diminuir as limitações desse Programa e não ampliam as possibilidades dos futuros professores de vivenciarem os diversos elementos que caracterizam o início da docência.
\end{abstract}

Palavras-chave: Programa de Indução à Docência Brasileiro, PIBID, Teoria Histórico-Cultural da Atividade, Programa de Residência Pedagógica.

CHANGES IN PIBID AND PRE-SERVICE TEACHER TRAINING: CHAT-BASED MULTILEVEL ANALYSIS

\footnotetext{
${ }^{1}$ Universidade de São Paulo. São Paulo, SP, Brasil.<leandrorabelo@usp.br>

${ }^{2}$ Universidade de São Paulo. São Paulo, SP, Brasil.<valeria.dias@usp.br>

${ }^{3}$ Universidade Estadual Paulista Júlio de Mesquita Filho. São José dos Campos, SP, Brasil.<fernando.carvalho@unesp.br> Educação em Revista|Belo Horizonte|v.36|e230963|2020
} 


\begin{abstract}
In this article we analyze some recent changes imposed on the Pre-service Teacher Training Scholarship Program (Programa de Bolsa de Iniciação à Docência -PIBID) which has been in place in Brazil since 2007. In the last decade, the Program has fulfilled an important task of better preparing undergraduates for the beginning of their teaching career. However, the last public note in 2018 significantly altered the structure of the Program, changing its formative potential. Based on the Cultural-Historical Activity Theory, we analyze part of the activities carried out under the PIBID Physics subproject of a federal university. The analysis was done on three levels. At the micro level, we analyze the short-term social situations that have enhanced the preparation for the beginning of the undergraduate students' teaching career on this subproject. At the mid-level we analyze the activity system of this subproject, highlighting the elements that contributed the most and which were limited in the training of future teachers. At the macro level we investigate how changes in PIBID, accompanied by the launch of the Pedagogical Residency Program, affected the activity system of PIBID. Our results indicate that these changes may lead to the detachment of PIBID from its identity as an initiation in teaching, undermining the efficiency of tutoring, diminishing the heterogeneity of the subproject subjects, and weakening the partnerships between universities and schools. In addition, these changes do not reduce the limitations of this program and do not expand the possibilities of future teachers to experience the various elements that characterize the beginning of teaching.
\end{abstract}

Keywords: Brazilian Teaching Initiation Program, PIBID, Cultural-Historical Activity Theory, Pedagogical Residency Program.

\title{
CAMBIOS EN EL PIBID Y EM LA PREPARACIÓN DE LOS MAESTROS PARA EL INICIO DE LA DOCENCIA: ANÁLISIS MULTI NIVEL BASADO EN THCA
}

RESUMEN: En este artículo analizamos algunos de los cambios recientes impuestos al Programa de Becas de Iniciación Docente (PIBID) vigente en Brasil desde 2007. El programa ha logrado en la última década una tarea importante de preparar mejor a los graduados para el comienzo de la carrera docente, pero la última convocatoria de 2018 cambió significativamente la estructura del Programa, alterando su potencial formativo. Basándose en la Teoría de la Actividad Histórico-Cultural, analizamos parte de las actividades desarrolladas bajo un subproyecto de Física PIBID de una universidad federal. El análisis se realizó a tres niveles. A nivel micro, analizamos las situaciones sociales a corto plazo que mejoraron la preparación para el comienzo de la enseñanza de los estudiantes de licenciatura del subproyecto. A nivel mediano analizamos el sistema de actividades de este subproyecto, destacando los elementos que más contribuyeron y que fueron limitados en la formación de futuros docentes. A nivel macro, investigamos cómo los cambios en el PIBID, acompañados por el lanzamiento del Programa de Residencia Pedagógica, afectan el sistema de actividad del PIBID. Nuestros resultados indican que estos cambios pueden llevar a la separación del PIBID de su identificación con el inicio de la docencia, ya que perjudican la eficiencia de la tutoría, disminuyen la heterogeneidad de los sujetos que componen el subproyecto y debilitan las asociaciones entre universidades y escuelas. Además, no contribuyen a reducir las limitaciones de este programa y no amplían las posibilidades de los futuros maestros para experimentar los diversos elementos que caracterizan el comienzo de la enseñanza.

Palabras clave: Programa de Inducción Docente Brasileño, PIBID, Teoría de la Actividad HistóricoCultural, Programa de Residencia Pedagógica. 


\section{INTRODUÇÃO}

Um dos persistentes problemas da educação na América Latina (AL) é a falta de professores com formação específica para trabalhar na educação básica. Segundo a UNESCO, na década de 1960 os países da AL contavam com uma média de $66 \%$ dos professores com formação certificada para o ensino básico primário. Na década de 2010, esse percentual passou para cerca de 78\%; e, no nível básico secundário, o percentual atingiu 70\%. A única exceção entre os países da AL está em Cuba, país que desde a década de 1960 conta com 100\% dos professores do ensino básico com formação certificada (UNESCO, 1962, 2014).

Em todos os países deficitários, as razões para a instauração do problema decorrem de múltiplos fatores, sendo alguns deles comuns a todos. Para combater esse problema, diversos países têm investido na criação de programas de apoio aos professores principiantes (GOLDRICK et al., 2012; JENSEN et al., 2012; EUROPEAN COMMISSION/EACEA/EURYDICE, 2015), e vários pesquisadores têm estudado iniciativas de aporte a esses professores (VAILLANT, 2009; ANDRÉ, 2012; MARCELO GARCÍA; VAILLANT, 2017). Em 2006, Marcelo García apresentou uma síntese desses programas, ressaltando a presença de tutores (professores experientes); diminuição da carga horária de trabalho sem redução de salário; cursos de formação continuada; criação de grupos de professores principiantes orientados por tutores, entre outros aspectos.

No caso específico do Brasil, contexto no qual situamos o presente estudo, o baixo número de professores com formação adequada decorre, sobretudo, da pouca atratividade da carreira e da alta evasão do magistério, causada, principalmente, pela precarização das condições de trabalho e pela desvalorização do trabalho docente (OCDE, 2006; KUSSUDA, 2012; PINTO, 2014).

A inadequação da formação docente no Brasil não se manifesta da mesma forma em todas as etapas da educação básica e difere também entre as disciplinas de uma etapa. Citamos como exemplo o caso da etapa do ensino médio, que, em 2019, registrou adequação na formação de $84,2 \%$ dos professores de Biologia, ao mesmo tempo que registrou que apenas 47,9\% dos professores de Física possuíam a formação adequada, ou seja, licenciatura em Física ou bacharelado em Física com complementação pedagógica (BRASIL, 2020). Tais percentuais preocupantes eram ainda menores uma década antes, o que levou o Conselho Nacional de Educação do País a elaborar um relatório sobre a escassez de professores no ensino médio (IBAÑEZ; RAMOS; HINGEL, 2007).

No referido relatório, foram propostas soluções emergenciais, bem como sete soluções estruturais para enfrentar o problema da falta de professores com formação adequada. Essas soluções estruturais consistiram na formação de professores por licenciaturas polivalentes; na estruturação de currículos envolvendo a formação pedagógica; na instituição de programas de incentivo às licenciaturas; na criação de bolsas de incentivo à docência; no estabelecimento de critério de qualidade na formação de professores por educação à distância; na integração da Educação Básica e o Ensino Superior e incentivo ao professor universitário que se dedica à Educação Básica (IBAÑEZ; RAMOS; HINGEL, 2007, p. 21-23). Algumas dessas propostas de soluções estruturais ganharam concretude, a partir de 2007, com a criação do Programa Institucional de Bolsas de Iniciação à Docência (PIBID), gerido pela Coordenação de Aperfeiçoamento de Pessoal de Nível Superior (CAPES).

Por meio do PIBID, são estabelecidas parcerias entre universidades (IES) e escolas de educação básica (EB), objetivando melhorar a formação inicial de professores, promover a retenção dos futuros professores nos cursos de licenciatura e melhor prepará-los para a inserção na realidade escolar. Este último objetivo ganha especial importância quando consideramos que o abandono da profissão docente ocorre principalmente nos primeiros anos da carreira. O choque com a realidade complexa e difícil das escolas de educação básica do País e a falta de apoio e de ações que ajudem o professor a lidar com as dificuldades levam ao abandono precoce da profissão docente e à atuação em outras áreas profissionais (DIAS; RABELO, 2017).

Assim, apesar de ser um programa voltado à formação inicial, o PIBID possui características similares às de programas para professores iniciantes, como os existentes em outros países da AL (RABELO; HANITA, 2018; RABELO; DIAS, 2019). Avaliações do Programa realizadas nos últimos dez anos (GATTI et al., 2014) apontam resultados bastante positivos, tais como a fixação dos estudantes 
nos cursos de formação inicial e o aumento da confiança para o exercício da docência. Contudo, mudanças profundas na estrutura do Programa foram efetivadas pela CAPES por meio de edital em 2018 (CAPES, Edital n. 07/2018), colocando em risco o suporte fornecido até então à formação de professores para o enfrentamento da fase inicial da carreira docente.

Objetivamos neste trabalho identificar essas mudanças na estrutura do Programa e analisar os impactos no seu funcionamento, bem como os desdobramentos na formação inicial dos professores. Para tanto, consideramos o PIBID como um sistema de atividades e realizamos uma análise em três níveis (micro, meso e macroestrutural) de dados provenientes de um Subprojeto de Física, com base na Teoria Histórico-Cultural da Atividade (THCA).

A análise no nível micro teve como objetivo entender como as atividades realizadas pelos bolsistas do Subprojeto de Física ajudaram a prepará-los para o enfrentamento futuro dos desafios do início da docência. Os resultados foram utilizados para a ampliação da análise no nível mesoestrutural, buscando a identificação das características e as ações desse Subprojeto que mais contribuíram e aquelas que se mostraram limitadas para a preparação dos licenciandos para o início na profissão. Por fim, os resultados obtidos nesses dois níveis permitiram, no nível macro, projetar como as mudanças no PIBID podem impactar a preparação dos licenciandos ao início da docência.

$\mathrm{Na}$ sequência, apresentamos alguns pressupostos teóricos da THCA que embasam esse trabalho, considerando o desenvolvimento de suas três gerações. Em seguida, explicitamos a metodologia utilizada na pesquisa, na qual situamos a coleta de dados em um subprojeto de Física, do PIBID, desenvolvido em uma universidade federal brasileira. Por último, apresentamos os resultados das análises realizadas, nos quais discutimos algumas mudanças na identidade do Programa e seu distanciamento do início da docência.

\section{TEORIA HISTÓRICO-CULTURAL DA ATIVIDADE}

A THCA teve origem com o desenvolvimento da psicologia histórico-cultural na antiga União Soviética com os trabalhos de Vigotski (1896-1934), Luria (1902-1977) e Leontiev (1903-1979). No ocidente, essa teoria foi amplamente difundida, sendo utilizada em diversas áreas.

Segundo Engeström (2001), a primeira geração da THCA foi desenvolvida com base na mediação, cultura e linguagem, tendo como unidade de análise o desenvolvimento e aprendizado individual. $\mathrm{Na}$ concepção vigotskiana, o aprendizado, isto é, o desenvolvimento de novas funções mentais superiores, ocorre por meio da internalização de instrumentos e signos desenvolvidos pela humanidade. Tal processo ocorre pela colaboração via imitação/criação, pois

[...] o momento central para toda a psicologia da aprendizagem é a possibilidade de que a colaboração se eleve a um grau superior de possibilidades intelectuais, a possibilidade de passar daquilo que a criança consegue fazer para aquilo que ela não consegue por meio da imitação. Nisso se baseia toda a importância da aprendizagem para o desenvolvimento, e é isto que constitui o conteúdo do conceito de zona de desenvolvimento imediato ${ }^{4}$. A imitação, se concebida em sentido amplo, é a forma principal em que se realiza a influência da aprendizagem sobre o desenvolvimento (VIGOTSKI, 2001, p.331).

A centralidade do conceito de Zona de Desenvolvimento Proximal (ZDP) na primeira geração da teoria evidenciou o processo de aprendizagem do sujeito na interação com o coletivo. Posteriormente, Leontiev (2004; 2010) distinguiu a ação individual da atividade coletiva, aprimorando o conceito de atividade ao defini-la como os processos que se dirigem a um objeto que satisfaçam determinadas necessidades, de modo que surge um motivo que impulsiona o sujeito a realizar a atividade. Para esse autor, a atividade é coordenada por ações que estão relacionadas aos seus objetivos. Tais ações, por sua vez, dependem das operações que são definidas pelas condições objetivas da atividade. Com isso,

\footnotetext{
${ }^{4}$ Aqui optamos por utilizar o conceito com a tradução de Zona de Desenvolvimento Proximal (ZDP), que corresponde à diferença entre o nível de desenvolvimento real, ou seja, aquilo que a criança consegue realizar sozinha, e o nível de desenvolvimento potencial, sua capacidade de realizar alguma tarefa com o auxílio de um adulto. Educação em Revista|Belo Horizonte|v.36|e230963|2020
} 
Leontiev avançou no entendimento da relação dialética entre o desenvolvimento da atividade e da consciência humana. Na terceira geração, Engeström expandiu a Teoria da Atividade, propondo um modelo para analisar a interação de sistemas de atividades coletivas. Esse modelo, o qual é tomado como unidade dialética de análise, pode ser representado como na Figura 1. Sem perder de vista essa unidade, o topo da figura apresenta o modelo triangular de Vigotski e evidencia a relação entre o sujeito e o objeto, através da mediação de artefatos materiais e culturais. A parte inferior da figura engloba as relações complexas dos sujeitos em uma atividade, dando destaque à inter-relação entre os sujeitos em uma comunidade e avançando no entendimento dos processos de transformação dos sistemas de atividades, incorporando "a estrutura do mundo social, com particular ênfase na natureza conflitual da prática social" (DANIELS, 2011, p.171).

Figura 1 - Sistema de atividade humana

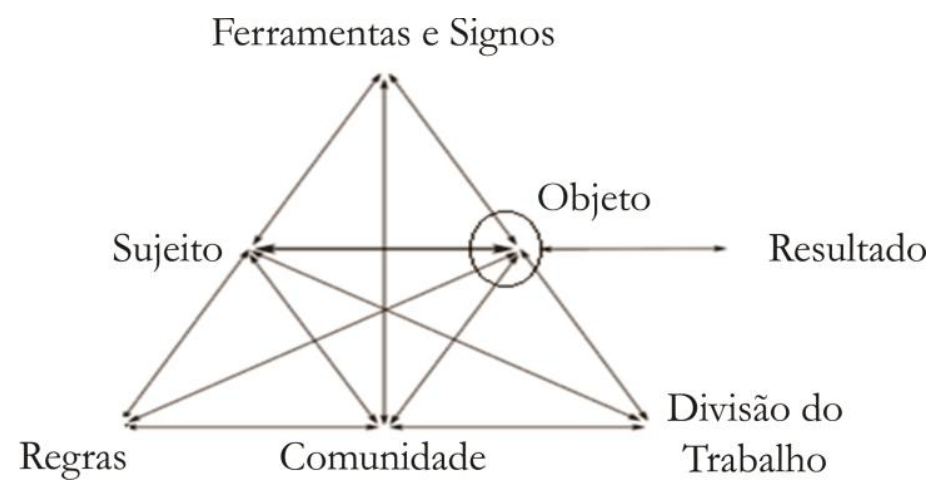

Fonte: Engeström, 2001, p.135, tradução nossa.

Nesse modelo, representado pela Figura 1,

o objeto refere-se à 'matéria-prima' ou 'espaço do problema' para o qual a atividade é direcionada. O objeto se transforma em resultados com a ajuda de instrumentos, isto é, ferramentas e signos. A comunidade abrange os indivíduos e subgrupos que compartilham o mesmo objeto geral. A divisão do trabalho refere-se à divisão horizontal de tarefas e à divisão vertical de poder e status. Finalmente, as regras referem-se aos regulamentos explícitos e implícitos, normas, convenções e padrões que restringem as ações dentro do sistema de atividade (ENGESTRÖM; SANNINO, 2010, p.6, tradução nossa).

O círculo na figura indica que "as ações orientadas para o objeto são sempre, explícita ou implicitamente, caracterizadas por ambigüidade, surpresa, interpretação, busca de sentido e potencial para mudanças" (ENGESTRÖM, 2001, p.134).

O modelo da Figura 1 representa apenas um sistema de atividade; porém, frequentemente, temos vários sistemas de atividade se relacionando em diferentes níveis hierárquicos (CAMILLO; MATTTOS, 2014). Dessas relações entre os sistemas e entre os elementos que compõem a atividade, podem surgir tensões e conflitos, exigindo modificações nos sistemas de atividade. Engeström (1987) chama de contradições a esses elementos que impulsionam a transformação da atividade. As contradições devem ser entendidas em sua concepção dialética, isto é, possuem elementos opostos em uma relação histórica e social que evolui com o tempo, "que tornam o objeto um alvo em movimento, motivador e gerador do futuro" (Engeström, 1987, p.5, tradução nossa). As contradições podem ser divididas em: contradição primária, a principal do sistema capitalista, que surge do conflito interno entre valor de troca e valor de uso, estando presente em cada um dos elementos do triângulo do sistema de atividade; contradição secundária, que tem origem na relação entre cada um dos elementos que compõem o sistema de atividade; contradição terciária, que aparece quando se introduz um objeto ou um motivo novo na 
atividade principal; e contradição quaternária, que surge quando há a influência de atividades vizinhas na atividade principal.

Como vemos, as contradições ocorrem não apenas dentro dos sistemas de atividades, mas, sobretudo, quando diferentes sistemas interagem, interferindo uns nos outros, o que pode impulsionar transformações nesses sistemas. Um exemplo de interação entre dois sistemas de atividades, representado pela Figura 2, ocorre quando eles compartilham um objeto em comum. As contradições que surgem dessa interação podem dar origem a um novo objeto ou um novo sentido ao objeto compartilhado.

Figura 2 - Interação de dois sistemas de atividade.

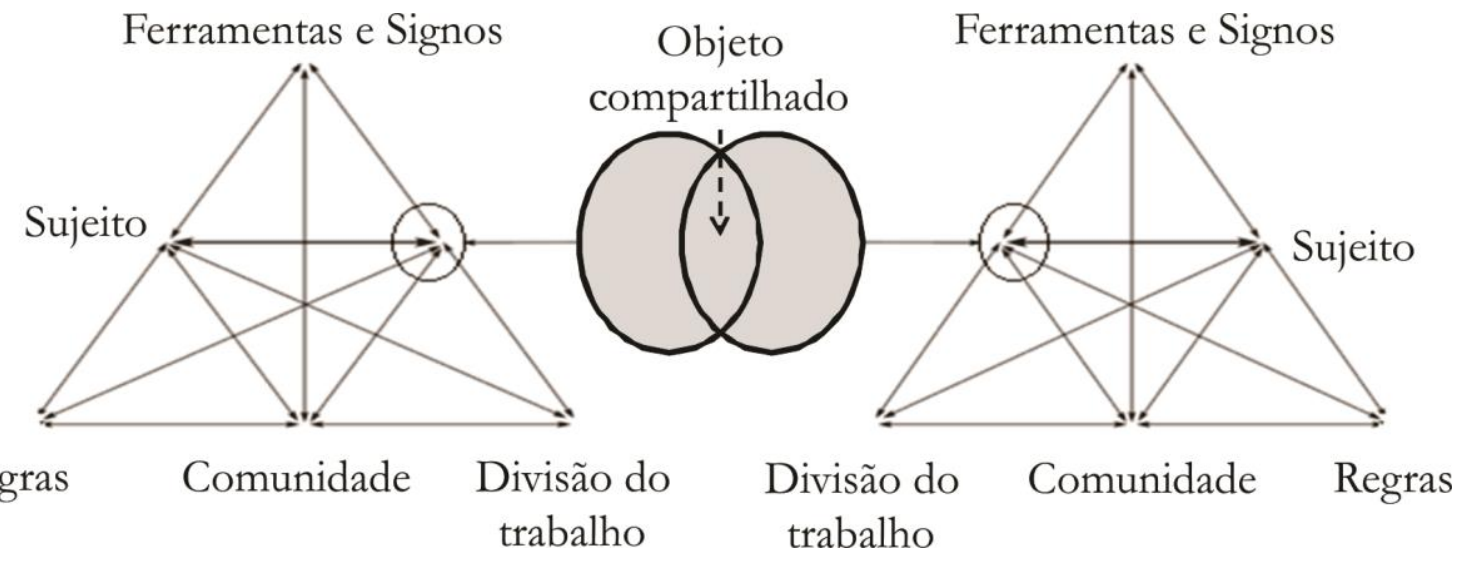

Fonte: Engeström, 2001, p.136, tradução nossa.

Neste trabalho, as contradições que emergiram em diferentes sistemas de atividade (PIBID, subprojeto e atividades dos licenciandos na escola) foram identificadas para a análise do impacto das mudanças provocadas por editais da CAPES em 2018 nas características do PIBID. Na seção seguinte, apresentamos a metodologia que utilizamos para considerar o PIBID como um sistema de atividade e identificamos as contradições que emergiram nesse sistema que impulsionaram a sua transformação.

\section{METODOLOGIA}

Consideramos que, para se ter um retrato da vida social, é fundamental analisar vários níveis da realidade social e a relação entre eles, sem considerar a priori que um nível seja mais importante que o outro. Optamos pela análise em três níveis, como definidos por Turner (2007, p. 386):

[...] o nível micro do encontro ${ }^{5}$, o nível meso das unidades corporativas (organizações, comunidades, grupos) e unidades categóricas (idade, sexo, classe, etnia) e o nível macro dos domínios institucionais (economia, política, parentesco, direito, ciência, educação), sistemas de estratificação (baseados na distribuição desigual de recursos), sociedades e sistemas de sociedades. (...) As forças de nível macro são população, produção, distribuição, regulação e reprodução, enquanto as forças de nível micro incluem emoções, necessidades transacionais, normatização, papéis, posições de status, forças demográficas e forças ecológicas. O nível meso é o tempo em que essas forças se encontram e são um resultado de sua operação conjunta.

Os três níveis (macro, meso e micro) constituem as três unidades de análise que estão hierarquicamente estruturadas no sistema de atividade (Figura 3). É importante ressaltar, com base na perspectiva histórico-cultural, que, ao dividir os fenômenos para análise, as unidades não representam a

\footnotetext{
${ }^{5}$ Situações sociais de curta duração que revelam interações entre os indivíduos e vivências do contexto da atividade. Educação em Revista|Belo Horizonte|v.36|e230963|2020
} 
separação em partes isoladas, mas são unidades de análise que possuem "todas as propriedades do todo que são inerentes ao todo e, concomitantemente, são partes vivas e indecomponíveis dessa unidade" (VIGOTSKI, 2009, p.8). Essas unidades de análise podem ser expressas em episódios que permitem expor e representar o fenômeno estudado em movimento (ARAÚJO; MORAES, 2017).

No nível macro, focalizamos o PIBID tendo em vista sua estrutura geral, como uma política pública de formação de professores, e apontamos como as recentes mudanças promovidas pelo Edital CAPES n. 06/2018 e o Edital CAPES n. 07/2018 afetam a preparação dos licenciandos para iniciarem a carreira docente. No nível meso estrutural, analisamos a organização particular de um Subprojeto do Programa, considerando as ações coletivas dos sujeitos pertencentes a esse grupo (bolsistas de iniciação à docência, coordenador de área e supervisor), e identificamos quais características favorecem (e quais limitam) a preparação dos futuros professores. No nível micro, focalizamos situações sociais de curta duração vivenciadas pelos bolsistas de iniciação à docência do Subprojeto, tendo em vista a preparação dos mesmos para o início da docência. Para cada nível, foi desenvolvida uma metodologia de obtenção de dados.

Na Figura 3, representamos o PIBID como sistema de atividade ligado a instâncias de nível superior (CAPES, Ministério da Educação etc.).

Figura 3 - Níveis hierárquicos de sistema de atividade do PIBID

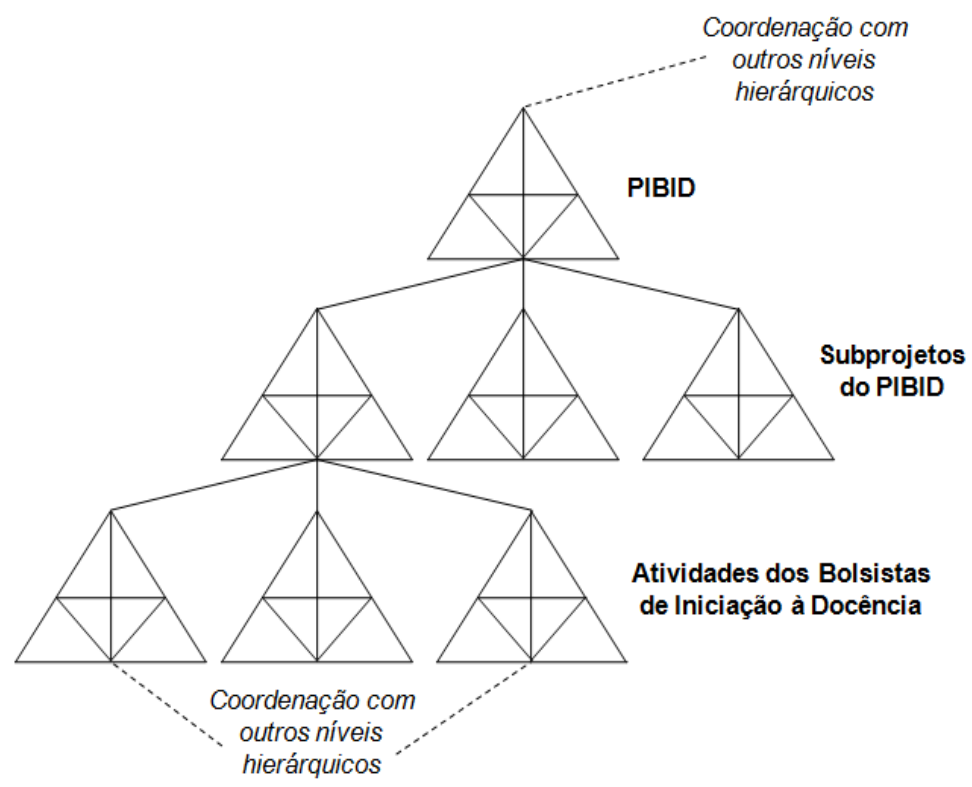

Fonte: elaborada pelos autores.

Ao considerarmos o PIBID um sistema de atividade, e o tomarmos como uma unidade de análise de nível macro, os subprojetos e a atuação dos bolsistas de iniciação à docência podem ser, respectivamente, ações e operações desse sistema.

Se considerarmos o Subprojeto como um sistema de atividade, tomando-o como unidade de análise de nível meso, a atuação dos bolsistas de iniciação à docência pode ser considerada ação desse sistema de atividade.

Por fim, ao considerarmos a atuação dos licenciandos na escola parceira como um sistema de atividade, no nível micro, são consideradas ações deste sistema aquilo que eles realizam na escola (observações de aulas, regências, avaliações etc.), as quais vão depender de outras condições objetivas da atividade (operações). 


\section{Nível micro}

No nível micro, analisamos as situações sociais de curta duração vivenciadas por cinco bolsistas de iniciação à docência de um subprojeto PIBID de Física de uma Universidade Federal. Esses sujeitos eram licenciandos do curso Licenciatura em Ciências em 2013, ano que realizamos coleta dos dados. Os licenciandos L1, L5, L2 e L3 estavam na primeira metade do curso, e L4 e L5 estavam concluindo a licenciatura e já atuavam como professores de educação básica. O subprojeto também contava com uma Coordenadora de Área (Coordenadora) e um Professor Supervisor (Supervisor) de uma escola estadual de ensino médio (escola parceira), situada em uma cidade da região metropolitana de São Paulo.

Os dados foram obtidos em duas fases: na primeira etapa, realizamos observações na universidade e na escola parceira, acompanhando reuniões dos integrantes do grupo (algumas foram gravadas em vídeo e, posteriormente, transcritas), encontros para a confecção de materiais didáticos e aulas dos bolsistas na escola parceira. As observações foram registradas em um caderno de notas e em seguida (dentro de vinte quatro horas) foram ampliadas, buscando-se o acréscimo de dúvidas, reflexões e resgate de memória dos acontecimentos. Além disso, outra fonte de dados importante foi um ambiente virtual (grupo na rede social facebook), no qual os integrantes registravam suas ações e reflexões durante as atividades do subprojeto.

$\mathrm{Na}$ segunda etapa da coleta de dados, realizamos entrevistas semiestruturadas com os licenciandos. Os roteiros de entrevista tinham um eixo comum e um eixo diferenciado. Com as questões do eixo comum, buscamos informações sobre a trajetória escolar, acadêmica, e sobre as atividades realizadas no PIBID. O eixo diferenciado foi construído com base nas informações obtidas na fase anterior e subsidiou a compreensão dos significados atribuídos pelos licenciandos às situações vividas.

Para a análise dos dados, selecionamos somente as situações sociais que apresentaram eventos marcantes no processo de desenvolvimento dos sujeitos. Em nosso caso, os eventos importantes são aqueles que apresentam contradições que impulsionaram as transformações do sistema de atividade, propiciando a vivência antecipada das dificuldades características do início da docência. Além disso, focalizamos as mudanças na apropriação de significados dos sujeitos em relação à docência. Para tanto, embasamo-nos na unidade dialética sentido/significado, definida por Leontiev (2004), na qual o sentido expressa os modos de apropriação das significações histórico-sociais (significados).

\section{Nível meso}

Para realizar a análise em nível meso, abordamos os mesmos dados considerados na análise do nível micro, com um foco diferente. Nesse caso, consideramos a organização geral do subprojeto de Física. Buscamos, assim, elaborar uma representação, com base no modelo do sistema de atividade (Figura 1), que evidenciasse as múltiplas relações estabelecidas no subprojeto, bem como a sua organização. Além disso, com base nessa representação, analisamos quais as características desse subprojeto que favoreceram (e quais não favoreceram) a preparação dos bolsistas licenciandos para o início da docência.

\section{Nível macro}

Para a análise do nível macro, utilizamos os resultados alcançados nos outros dois níveis e os dados obtidos em documentos oficiais. Em especial, refletimos sobre como as recentes mudanças na estrutura geral do PIBID, promovidas pelo Edital n. 07/2018 da CAPES, podem afetar a preparação dos bolsistas licenciandos para o início da docência. Em outras palavras, como as mudanças no nível macro afetam as relações que se estabelecem nos níveis meso e microestruturais. 


\section{RESULTADOS}

A apresentação dos resultados da pesquisa está organizada pelos níveis. Um primeiro movimento de análise é realizado ao longo da apresentação dos dados, identificando e interpretando as contradições em cada unidade de análise. No fim da apresentação de cada nível, um segundo movimento analítico é realizado, ampliando as possibilidades interpretativas.

\section{Nível microestrutural}

As situações sociais que compõe o conjunto de dados dessa análise estão representadas em três episódios vivenciados pelos bolsistas de iniciação à docência na escola de Educação Básica e na universidade. Esses episódios estão relacionados a alguns dos principais desafios enfrentados pelos professores em início de carreira (LIMA et al., 2007): falta de materiais adequados para desenvolver atividades durante as aulas, dificuldades para avaliar a aprendizagem dos alunos e escassez de repertório para lidar com a indisciplina dos alunos.

\section{$1^{\circ}$ episódio - falta de materiais para as aulas}

Entre os cinco bolsistas do subprojeto, a licencianda L2 era a mais insegura em relação a estar diante dos alunos em sala de aula e quanto ao domínio dos conteúdos de Física. Essa insegurança era bastante clara para o grupo, inclusive para a Coordenadora que buscava motivá-la.

Postagem no grupo do facebook - 06 de agosto de 2013

Coordenadora - L2 vá confiante, demonstre segurança, tudo vai dar certo.

L2 - Estou confiante, estou estudando para dar tudo certo. Obrigada professora! Vai ser um desafio, mas de ontem para hoje acho que aprendi mais do que na época de escola! Pode deixar que depois posto no facebook! Coordenadora - Com certeza!! Boa sorte L2, estou na torcida!

Depois da regência, como era comum entre os licenciandos, L2 postou no grupo do facebook suas impressões sobre as aulas:

\section{Postagem no grupo do facebook - 7 de agosto de 2013}

L2 - Olá pessoal, hoje foi a $1^{\text {a }}$ aula sobre Newton na escola com o $1^{\circ} \mathrm{A}$. Cheguei lá com tudo preparado, mas me deparei com um problema técnico no computador da sala de vídeo (faltava um cabo), ou seja, não consegui usar o slide que preparei. (...) Fiquei bem nervosa. Mas enfrentei. Fui lá e comecei a explicar as Leis, dei exemplos. Trabalhei as fórmulas com eles, e o L3 ajudou com exemplos! Quando vi que eles estavam participando e entendendo foi muito legal. Ainda mais porque eu quem estava explicando um conceito das exatas. Agora acho que até estudar vai ser melhor! O L3 ajudou muito!!

Com a superação das dificuldades, ela manifestou mais confiança e, em outros momentos, conseguiu lidar sozinha com os problemas que apareceram.

Postagem no grupo do facebook - 13 de agosto de 2013

L2 - Novamente por falta de recursos do projetor e também pela sala de vídeo estar sem cadeiras, a aula novamente ocorreu na sala de aula mesmo. Dessa vez toquei a aula sozinha mesmo, só eu e a sala.

Nesse episódio, L2 deparou-se com uma contradição secundária entre as ferramentas e signos (computador, datashow e slides) e seu objeto (ensinar as Leis de Newton aos alunos), que modificou as condições de realização de sua prática de ensino-aprendizagem. Isso exigiu a mobilização de outras ações e operações (exemplos, lousa, ajuda do colega etc.), levando à transformação da atividade. Dessa maneira, a contradição teve o papel de impulsioná-la a superar a sua insegurança e ampliar sua compreensão sobre a docência. Sua insegurança, aliada ao problema de indisponibilidade de recursos, deu lugar à satisfação de perceber os alunos aprendendo. Com isso, houve a emergência de novos sentidos sobre a docência. Seus sentidos sobre a docência, os quais refletiram insegurança com ensino 
de conceitos de exatas, passaram a contar com novos conteúdos, relacionados à superação e à satisfação com a atividade docente, os quais são importantes para a sustentação do professor, sobretudo nas fases iniciais da carreira. Para a emergência desses novos sentidos atribuídos à experiência por L2, foi importante o apoio afetivo, emocional e técnico de outros membros do grupo, possibilitando o desenvolvimento de novos conhecimentos sobre a atividade docente. Situações como essa eram utilizadas nas reuniões do grupo como fontes de aprendizado para os licenciandos.

\section{Transcrição da reunião do dia 31 de outubro de 2013}

Coordenadora - Todo mundo teve problema com o datashow. (...) Então, a primeira lição: tem que ter um "plano A" e um "plano B" sempre. (...) O que a gente poderia fazer para ter um "plano B" no caso de uma aula muito pautada em imagens?

A partir dessa problematização, os licenciandos levantaram diversas possibilidades para lidar com a falta de materiais na escola, discutindo as limitações e potencialidades de cada uma delas. Dessa maneira, a contradição gerada pela dificuldade em lidar com a falta de materiais adequados na escola caracterizou-se não apenas como um momento de angústia e frustração para a bolsista L2, mas, sim, um momento de aprendizado coletivo sobre a docência. Essa contradição, ao impulsionar mudanças na atividade, levando à superação de desafios pessoais para L2, possibilitou a atribuição de novos sentidos relacionados à docência e ao desenvolvimento de sua consciência como futura professora.

\section{$2^{\circ}$ episódio - dificuldade de avaliar os alunos}

Ao fim dos semestres, os bolsistas aplicaram instrumentos para avaliação da aprendizagem dos alunos com o intuito de mapearem as mudanças necessárias no planejamento das regências. Uma dessas avaliações foi aplicada pelos bolsistas L1 e L5. Finalizadas as avaliações, eles se reuniram na sala de professores para corrigir as respostas dadas pelos alunos às questões e discutir os critérios de avaliação.

\section{Observação na escola parceira no dia 01 de novembro de 2013}

Eles (L5 e L1) seguiram maneiras diferentes de corrigir as questões e discutiram bastante sobre os critérios para considerar uma questão certa, meio certa ou errada. [...] As respostas das que tinham alternativas foram as mais discutidas pelos dois bolsistas. A controvérsia estava no fato de muitos alunos colocarem apenas a alternativa que achavam correta sem demonstrarem como chegaram ao resultado. Para o L5, esses deveriam receber meio certo nessas questões, mas, para L1, a questão deveria ser zerada.

Nesse episódio, analisando a tarefa de avaliar a aprendizagem dos alunos como uma atividade, podemos considerar que os critérios de avaliação se constituem como ferramentas adotadas pelos licenciandos. Assim, esse episódio evidencia uma contradição secundária entre as ferramentas (critérios de avaliação) e o objeto da atividade dos bolsistas (avaliar a aprendizagem dos alunos).

Tal contradição ocorreu devido ao fato de a correção das respostas dos alunos ter sido realizada coletivamente. Isso propiciou o conflito entre os sentidos atribuídos pelos licenciados à atividade de avaliação dos alunos, mais especificamente em relação ao que considerar como parâmetro de avaliação da aprendizagem dos discentes. Cada um deles atribuía um sentido específico à avaliação da aprendizagem dos alunos, tendo em vista as suas próprias vivências com essa atividade, quer no papel de alunos, quer no de professores. No caso da bolsista L1, que ainda não tinha tanta experiência docente, os seus sentidos faziam com que ela mantivesse uma posição mais rígida em relação às respostas dos alunos; no caso do bolsista L5, que já atuava como professor na educação básica, os seus sentidos levavam-no a ser mais flexível nas correções de suas questões. reuniões do grupo.

Questões como essa, sobre critérios e instrumentos de avaliação, foram discutidas nas

\section{Transcrição da reunião do dia 04 de novembro de 2013}

Coordenadora - Ótimo. Agora vamos para parte do L5, mas ele não está aqui. Você fala por ele L1? Ele comentou o que ele corrigiu?

L1 - Ele deve estar com muita raiva. (...) Na hora da correção eu perturbei tanto ele. (...) A minha questão Educação em Revista|Belo Horizonte|v.36|e230963|2020 
número dois tinha alternativa e na avaliação dele, a questão quatro, também tinha. Quem não justificava, eu dei errado. O L5 falava: não L1 é meio. Eu dizia, está errado e tem que justificar.

Coordenadora - Então, eles foram mal na parte do L5 também?

L1 - Foram melhores porque muitos justificaram a questão do L5.

Coordenadora - Independente da nota, esquece a nota, em termos do desempenho deles, eles conseguiram fazer? (...) O que é importante, vocês identificarem o que ficou frágil para reforçar na devolutiva?

$[\ldots]$

Coordenadora - Agora, por exemplo, L1 você chegou a trabalhar algum exercício deste tipo em aula?

L1 - Que eu me lembre, não. Exercício não. Eu mostrei só.

Coordenadora - Então, vocês acham que a gente podia esperar que eles se saíssem bem nesse? Em face do que nós demos a eles?

L1 - Não! (risos) que era primeira vez que eles faziam o exercício. (...) Então pensei, mas não foi suficiente, acho que devia ter feito um exercício com eles lá, na hora!

Coordenadora - Primeira conclusão. Erro nosso. Nós cobramos matematização sem ter ensinado. Erro nosso.

A Coordenadora apontou uma incoerência no processo avaliativo, evidenciando a contradição secundária entre a ferramenta (critérios de avaliação) e o objeto (avaliar a aprendizagem alunos), o que mobilizou os sujeitos a refletirem sobre questões importantes relacionadas à avaliação, tais como: objetivo da avaliação, critérios e instrumentos coerentes de avaliação. Assim, essa discussão coletiva favoreceu a ressignificação dos sentidos atribuídos pelos licenciandos à avaliação da aprendizagem dos alunos. Isso ocorreu devido à confrontação dos múltiplos sentidos dos sujeitos que faziam parte do subprojeto. Portanto, nesse caso, podemos perceber que avaliar os alunos se tornou mais do que um momento de angústia ao se depararem com dificuldades de aprendizagem dos estudantes: foi sobretudo uma experiência de aprendizado, porque os licenciandos tiveram a oportunidade de construir e de testar os instrumentos de avaliação que utilizaram, transformando a avaliação em uma atividade de diagnóstico e ponto de partida para o planejamento de outras atividades.

\title{
$3^{\circ}$ episódio - lidar com a indisciplina dos alunos
}

Em uma das aulas dos bolsistas L3 e L4, os alunos estavam muito agitados. Em vários momentos, os bolsistas tiveram que chamar a atenção dos alunos.

\begin{abstract}
Observação na escola parceira no dia 12 de novembro de 2013
L3 novamente chamou atenção dos alunos, pois estavam conversando muito: "sei que é a última aula (...), mas, por favor, é importante discutir como foi a avaliação". (...) Em seguida, L3 continuou a explicar: "a história não tem verdades absolutas (...), pois as pessoas contam a história como veem”(...). Nesse momento, L3 passou a condução da aula para o bolsista L4. Este começou cumprimentando os alunos com bom dia. Os alunos ficaram mais calmos e L4 disse que iriam relembrar plano inclinado e polias (...). Os alunos estavam bem menos agitados, mas um aluno estava conversando muito, fazendo alguns gestos como se dançasse.

Então, L4 o chamou. (...) O aluno voltou para o seu lugar e parou de conversar. O bolsista continuou a explicação sem ter tantos problemas como L3.
\end{abstract}

Depois dessa aula, L3 relatou suas impressões no grupo do facebook:

Postagem no grupo do facebook - 12 de novembro de 2013

L3 - A sala $\left(1^{\circ} \mathrm{C}\right)$ estava muito dispersa, talvez por conta de alguma intriga causada por um aluno (...). $\mathrm{Na}$ minha devolutiva, poucos alunos mostraram-se empenhados. Foi uma experiência cansativa. (...) Quanto à aula do L4, foi muito dinâmica, divertida. Conseguiu um controle um pouco melhor que o meu, mas ainda assim, eles continuavam distraídos.

Neste episódio, percebemos que os bolsistas L3 e L4 se deparam com uma contradição secundária entre os sujeitos da atividade de ensino-aprendizagem (licenciandos e alunos da educação básica). Essa contradição tem foco nas diferenças de sentidos atribuídos pelos licenciandos e pelos alunos à devolutiva dos resultados da avaliação e parece ter sido mais significativa para o bolsista L3, que teve mais dificuldades para lidar com o comportamento inesperado dos alunos. O trabalho conjunto com L4 permitiu que se encontrasse outra possibilidade para lidar com a indisciplina, pois, como L4 tinha mais 
experiência na atuação como professor, demonstrava maior facilidade para lidar com as diversas situações da sala de aula, transmitindo segurança aos outros bolsistas.

Essas três experiências vivenciadas pelos bolsistas de iniciação à docência, a partir da emergência das contradições, impulsionaram a transformação das atividades. Considerando a unidade dialética entre atividade e consciência (Leontiev, 2010), podemos afirmar que há indicativos de que houve também o desenvolvimento da consciência dos licenciandos como professores. Isso ocorreu porque as contradições que emergiram nas atividades foram utilizadas para problematizar questões importantes da atividade profissional docente, possibilitando aos sujeitos o compartilhamento de sentidos sobre diferentes aspectos da docência: como criar um repertório didático; como realizar atividades avaliativas; e como lidar com a indisciplina dos alunos. Isso permitiu aos bolsistas licenciandos a vivência antecipada, de forma amparada, de alguns dos elementos que caracterizam o início da carreira docente.

O primeiro episódio marca a atuação de L3 como o parceiro mais capaz, que auxiliou a bolsista L2 a superar os receios de conduzir uma atividade de ensino de Física e a transitar, assim, da Zona de Desenvolvimento Real à Zona de Desenvolvimento Potencial. No segundo episódio, a divergência nos critérios de avaliação utilizados por L1 e L5 estava relacionada à diferença de experiência com esse tipo de atividade. L5 atuava como professor no ensino básico e já havia realizado diversas vezes atividades dessa natureza. Já L1 estava realizando suas primeiras atividades avaliativas como professora. Desse modo, quando debateram sobre os critérios de avaliação, atuaram um sobre a ZDP do outro, levando-os a se questionarem sobre os sentidos atribuídos à avaliação. No terceiro episódio, diante de um mesmo contexto em que o comportamento dos alunos prejudicava o andamento da aula, a atuação do bolsista L4 serviu como exemplo, para o bolsista L3, de como lidar com situações de indisciplina.

A interiorização dessas práticas não se dá apenas por imitação, com base nos pressupostos teóricos de Vigotski; entendemos que os sujeitos também criam a partir dos elementos histórico- culturais disponíveis e dentro de suas ZDP. Isto é, há um processo dialético de imitação-criação que é fundamental para o desenvolvimento profissional docente. Isso ocorre porque

[...] a criação docente não se produz do nada. O professor movimenta seu percurso formativo, com sentidos que são produzidos por ele na sua relação com a cultura por meio da apreensão de conceitos relacionados à sua área de formação específica e à área do ensino, experiências anteriores como docente e estudante; enfim, referências da realidade concreta que são sua base para, continuamente, produzir sua atividade profissional. Essas referências reconfiguram-se à medida que são promovidos conflitos de toda ordem, contribuindo para que ele se desenvolva (SOUSA; LONGAREZI, 2018, p.445).

A seguir, passamos à análise do segundo nível hierárquico de atividade.

\section{Nível mesoestrutural}

Optamos por apresentar a análise dividindo-a em duas partes, uma tratando das contribuições e outra, das limitações do subprojeto para preparar os bolsistas licenciandos para o início de docência.

\section{Contribuições do Subprojeto}

A análise realizada no nível micro permite-nos perceber que o subprojeto se constituiu como um ambiente colaborativo de formação, no qual os bolsistas puderam relatar, discutir, refletir e ressignificar as experiências que estavam vivendo na escola parceira. Para isso, foi importante o estabelecimento de um grupo colaborativo heterogêneo, composto por uma coordenadora de área, um professor supervisor, licenciandos em fases iniciais do curso de licenciatura e outros no final do curso, que já atuavam como professores iniciantes na EB; logo, sujeitos com ZDP diferentes e que, em colaboração, puderam compartilhar experiências e aprendizados. Isso possibilitou aos futuros professores realizarem atividades que, sozinhos, não conseguiriam pôr a termo, ou para as quais teriam mais dificuldades. 
Para investigar os fatores que possibilitaram ao subprojeto favorecer a preparação para o início da docência, analisamos o seu sistema de atividade. Sem perder de vista a unidade dialética da atividade, ao analisar algumas das tríades de mediação do sistema de atividade do subprojeto, podemos perceber algumas características que contribuíram para a preparação dos licenciandos para o início da carreira docente. Para facilitar a identificação das tríades de mediação, na Figura 4 apresentamos o sistema de atividade do subprojeto PIBID de Física analisado.

Figura 4 - Sistema de atividade do subprojeto PIBID de Física analisado ${ }^{6}$

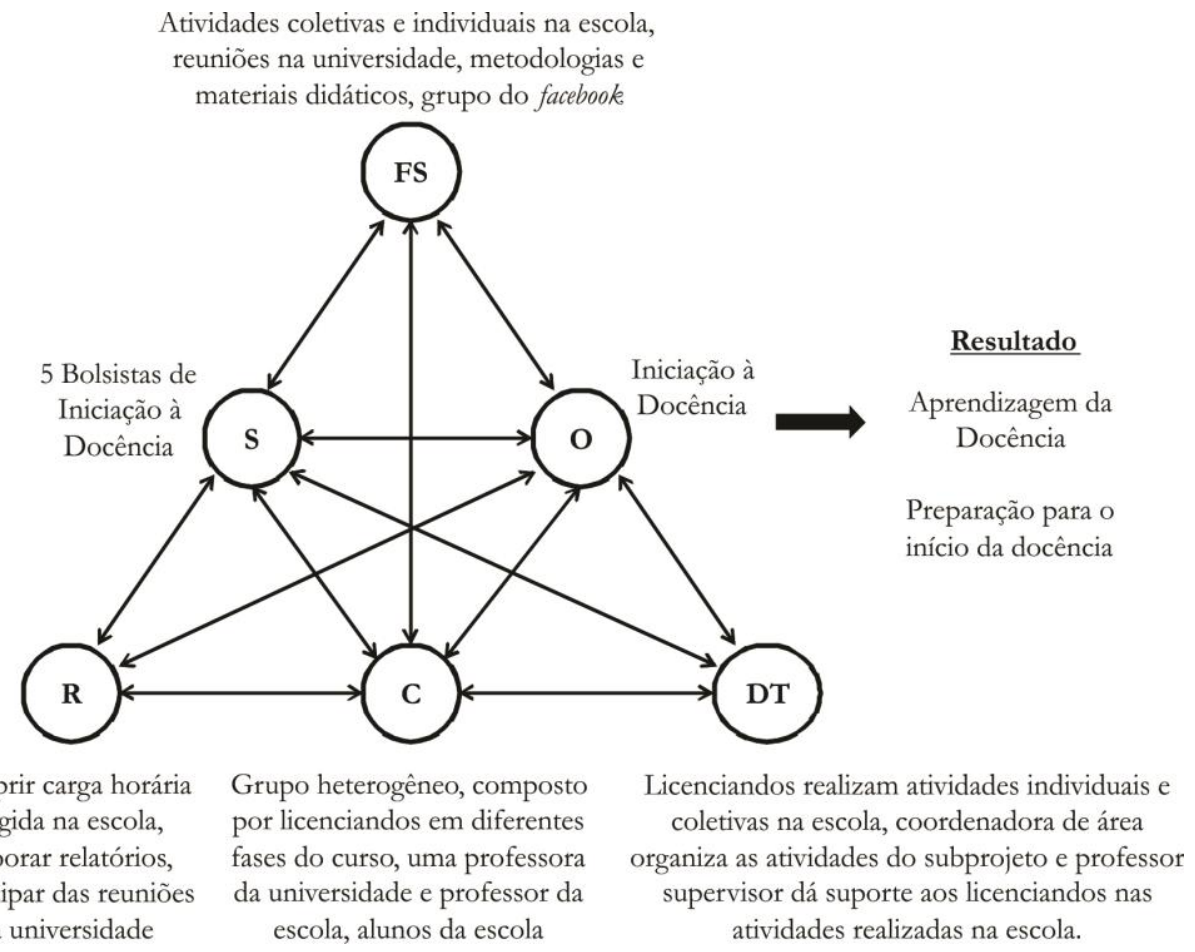

Fonte: elaborada pelos autores

Sujeito/Ferramentas e Signos/Objeto: essa tríade revela que, para atender as necessidades de iniciação à docência, os sujeitos desse subprojeto elaboraram diversos instrumentos (ferramentas e signos) de mediação para essa atividade. Destacamos dois espaços de comunicação/trocas entre os sujeitos: as reuniões semanais do grupo e o grupo do facebook. As reuniões, além de viabilizarem a organização das atividades, o aprofundamento teórico e as discussões das atividades individuais e coletivas, também possibilitaram o compartilhamento de angústias e satisfações pelos sujeitos. O grupo do facebook facilitava a comunicação entre os sujeitos, mantendo-os atualizados em relação às atividades do subprojeto. O facebook também serviu para o grupo compartilhar ideias e se amparar, incentivando uns aos outros nos momentos que antecediam as regências, ou após cada intervenção realizada.

Sujeito/Comunidade/Objeto: a constituição de um grupo heterogêneo foi fundamental para ampliar as experiências e conhecimentos disponíveis para o grupo. Havia sujeitos em diferentes fases da formação docente. Uns estavam na primeira metade do curso de licenciatura (L1, L2 e L3) e outros estavam finalizando o curso (L4 e L5) e já atuavam na educação básica como professores (uma realidade bastante comum no Brasil). Além do mais, havia dois professores experientes, um da universidade (coordenadora) e outro da escola de educação básica (supervisor). Isso possibilitou trocas mais ricas entre os sujeitos, e, através da imitação-criação, puderam atuar uns sobre a ZDP dos outros, enriquecendo as vivências no subprojeto.

\footnotetext{
${ }^{6}$ Os símbolos nos círculos representam os elementos do sistema de atividade: sujeitos (S), ferramentas e signos (FS), objeto $(\mathrm{O})$, divisão do trabalho (DT), comunidade (C) e regras (R). 
A estrutura do PIBID, ao permitir que alunos de várias fases do curso participassem de um mesmo subprojeto, possibilitava a diversidade das experiências compartilhadas, o que é fundamental para a formação do futuro professor.

Sujeito/Divisão do Trabalho/Objeto: a coordenadora de área e o supervisor desempenhavam, dentro da divisão do trabalho, as tarefas sob sua responsabilidade com empenho e dedicação. Alguns trechos das entrevistas com os bolsistas revelam a dedicação de ambos.

\footnotetext{
Transcrição de entrevistas

L2 - Porque, eu acho ela extremamente inspiradora. A coordenadora é incrível! Ao mesmo tempo que ela entende de Física, também entende de humanas por causa da História da Ciência. Ela é uma pessoa que nas reuniões conseguia trazer textos. Então não era só uma aula de Física, era uma aula de Física com conteúdo também de humanas, e era discutido.

L2 - Ele (supervisor) era super tranquilo, super presente, dava liberdade pra gente trabalhar com os alunos. Tudo que a gente pedia em questão de reservar a sala, preparar xerox, essas coisas que a gente estava precisando, ele era bem solícito. Participava das reuniões com a gente, era bem tranquilo!

L1 - A coordenadora e o supervisor priorizavam muito a nossa preparação pra ir pra sala de aula (...) Criava atividades e levava pro grupo discutir. A gente fazia, claro, várias modificações, depois das várias críticas que a gente tinha que escutar. Então foi um longo processo até ir pra sala de aula.

L3 - A professora coordenadora é minha mãe acadêmica, é uma relação realmente maternal. É mais do que uma relação, é um vínculo que transpõe. (...) Ele (supervisor) era uma pessoa, como eu estou te falando, ele deixava a sala de aula em nossas mãos e só fazia intervenções quando achava realmente e estritamente necessário. Então ele não deixava, ele não abalava a nossa autoridade que a gente tinha temporariamente ali com os alunos, só quando (eu falei) só quando era extremamente necessário. (...) O professor supervisor tinha a postura de que ele tinha a aprender conosco, enquanto a gente também tinha a aprender com ele, era uma relação de troca.
}

Como podemos perceber, o trabalho dos dois professores (coordenadora e supervisor) não se limitava aos aspectos burocráticos da divisão de trabalho exigida. Eles compartilhavam conhecimentos teóricos e práticos e, também, davam suporte emocional, auxiliando e amparando as dificuldades encontradas pelos bolsistas de iniciação à docência.

Sujeito/Regras/Objeto: além das regras gerais estabelecidas pelo PIBID, outras estabelecidas no interior do grupo - como, por exemplo, a exigência da participação de todos nas reuniões e a necessidade de postarem no facebook a descrição e a impressão das intervenções realizadas na escola - foram essenciais para ampliar a comunicação e as trocas entres os participantes do subprojeto. Esses elementos contribuíram bastante para a dinâmica formativa do grupo.

Essas características e ações do subprojeto evidenciam que houve a complexificação e ampliação dos mediadores da atividade. Isso possibilitou a elaboração de instrumentos, regras e divisões de trabalho condizentes com os objetivos do Programa, isto é, a melhoria da formação inicial de professores. Além disso, permitiram um espaço rico de vivências coletivas e trocas que favoreceram a preparação dos licenciandos para enfrentarem os desafios do início da docência.

\section{Limitação do Subprojeto}

O início da carreira docente é uma das fases mais intensas e críticas pelas quais o professor passa durante sua vida profissional (MARCELO GARCÍA, 1991; HUBERMAN, 1995; TARDIF, 2000). Embora vivencie as mesmas dificuldades que os professores mais experientes, os professores novatos as experimentam "com maiores doses de incertezas e estresse devido a possuírem menos referências e mecanismos para enfrentar estas situações" (VAILLANT, 2009, p.35, tradução nossa). Sánchez (2012, p. 21-22) indica os principais problemas que os professores iniciantes enfrentam: "manter a disciplina da classe, motivar os estudantes, lidar com as diferenças individuais, avaliar o trabalho do aluno, relacionarse com os pais dos alunos, organizar o trabalho de classe, contar com materiais suficientes e adequados para ensinar e lidar com problemas individuais dos estudantes" (tradução nossa).

De modo complementar, Lima et al. (2007) evidenciam que, entre as dificuldades enfrentadas pelos professores iniciantes, está a falta de amparo institucional tanto da escola como dos 
órgãos gestores, a dificuldade em lidar com o baixo interesse e indisciplina dos alunos e a dificuldade para lidar com os pais dos alunos. Colombo Júnior (2009), ao pesquisar as dificuldades enfrentadas por professores principiantes de Física e Matemática, acrescenta que esses professores reclamam da proposta curricular indicada por órgãos gestores, pois há "uma discrepância entre suas crenças daquilo que pode ser uma boa aula e o que é proposto pela escola" (ibidem, p.7).

Com base nessas pesquisas, a Figura 5 apresenta um sistema de atividades que sintetiza os desafios enfrentados pelos professores iniciantes.

Figura 5 - Sistema de atividade de um professor iniciante

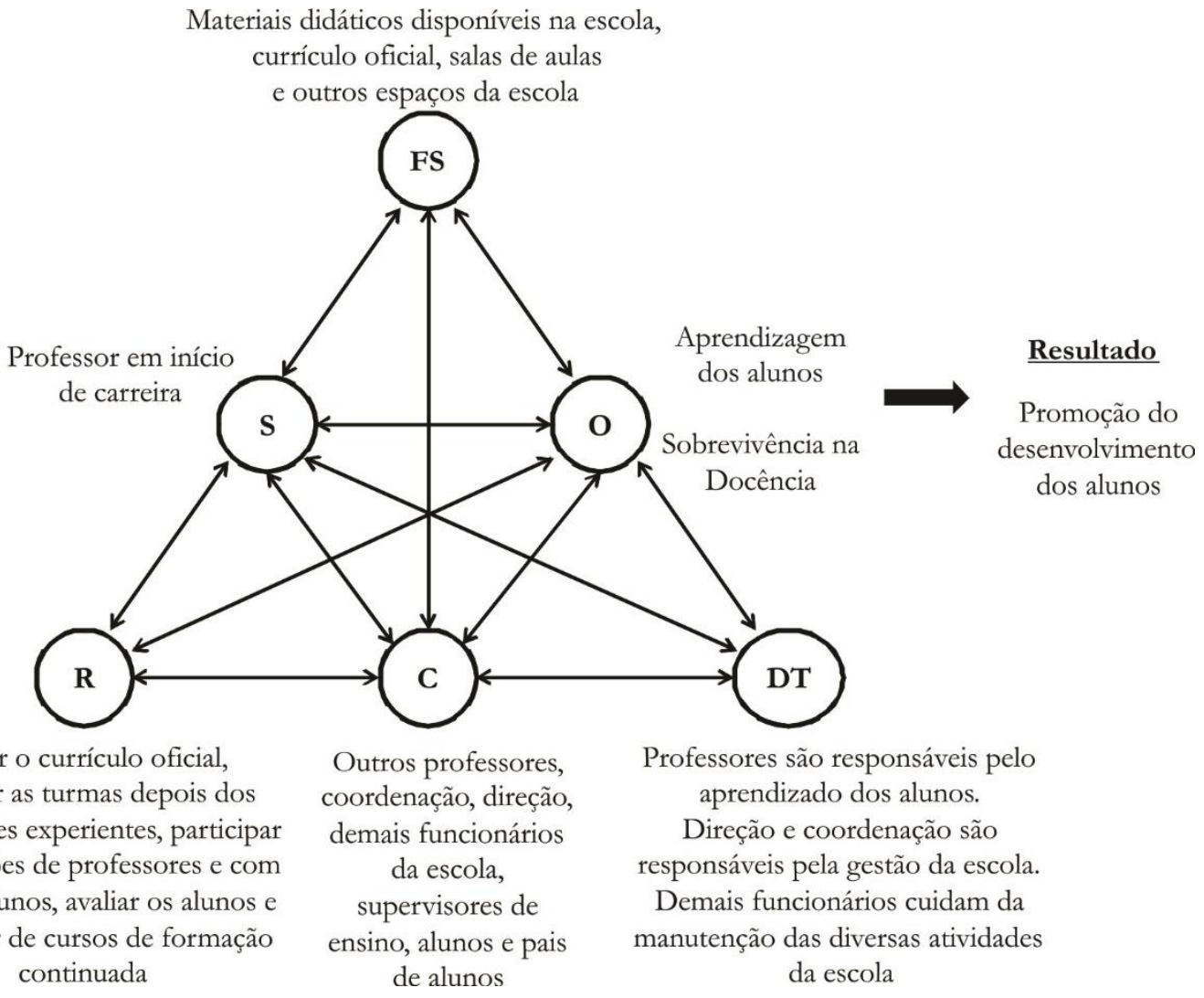

Fonte: elaborada pelos autores.

Essa representação não abarca todas as dificuldades que um professor pode enfrentar no início da carreira, mas revela aspectos gerais da atividade docente de ensino básico. Analisando os dois sistemas de atividade (Figura 3 e 4), podemos perceber que, entre as limitações do subprojeto, se destacam a restrição das relações a uma parte da comunidade da escola e a simplificação das regras quando comparadas àquelas de um professor em início de carreira. Os licenciandos não precisaram elaborar um planejamento anual de ensino, preencher diários de classe, participar de reuniões com outros professores e/ou com os pais de alunos ou participar da gestão da escola. Além disso, não tinham a responsabilidade efetiva pela avaliação dos alunos e não precisaram seguir o currículo oficial. A divisão do trabalho para um bolsista de iniciação à docência foi também muito menos complexa que a de um professor em início de carreira. As relações entre a comunidade escolar, coordenação, supervisão e os bolsistas no PIBID foram mais horizontalizadas quando comparadas às encontradas pelos professores principiantes em suas relações dentro de comunidades escolares que envolvem muito mais sujeitos.

Assim sendo, os licenciandos não vivenciam no PIBID todas as dificuldades que podem emergir do contexto escolar, mas é importante destacar que isso é esperado. Mesmo que em alguns outros subprojetos do PIBID se manifestem atividades que favoreçam o contato com os outros 
elementos da docência - através, por exemplo, da análise de documentos escolares, de reuniões com professores e com pais de alunos -, não é possível que os futuros professores vivenciem em sua totalidade os elementos que caracterizam o complexo quadro de atividades do espaço escolar. A responsabilidade que os licenciandos possuem sobre a aprendizagem e a avaliação dos alunos é sempre parcial, o que lhes confere outros sentidos sobre as intervenções que realizam nas escolas.

Essas características, aparentemente limitadoras do subprojeto PIBID analisado, são importantes para a vivência gradual dos elementos da profissão. A inserção gradual na carreira possibilita a experiência em um nível de dificuldade que é mais adequado com a ZDP dos futuros professores. Quando isso não ocorre e há uma inserção brusca no contexto escolar, a necessidade de lidar com todos os elementos que constituem a profissão docente de uma só vez, e de forma solitária, pode gerar um nível de tensão e angústia fatal para a continuidade na carreira.

\section{Nível macroestrutural}

Algumas das características gerais do PIBID o aproximam de outros programas de iniciação ou indução à docência, vigentes em outros países, como pode ser verificado comparando-se algumas de suas características com as de outros programas (RABELO; DIAS, 2019). Destacamos, para isso, elementos centrais de programas de indução à docência, conforme identificados por Marcelo García (2006, p.15).

1. Orientação: esta é uma atividade introdutória que ocorre antes do início na escola, para que os novos professores conheçam algo sobre a escola, o currículo, a comunidade;

2. Mentoria (professor da educação básica responsável por acompanhar o professor novato): este é talvez o fator mais importante nos programas de inserção, elemento muito presente devido ao seu baixo custo;

3. Ajuste nas condições de trabalho: geralmente o número de alunos é reduzido nas classes dos professores principiantes, as atividades extracurriculares são reduzidas, são fornecidos materiais e recursos, é proporcionado treinamento para os professores novatos;

4. Redução de carga didática para permitir que os professores principiantes possam realizar atividades de formação;

5. Desenvolvimento profissional: são realizadas atividades de formação que podem estar relacionadas com o ensino, com a gestão da sala de aula, com a disciplina e com o relacionamento com os pais dos alunos;

6. Colaboração com os pares: a troca de experiências ocorre em grupos de professores que planejam e analisam a prática docente. Esta colaboração é importante porque reduz a sensação de isolamento;

7. Avaliação do professor: periodicamente os professores iniciantes são observados em suas práticas, para identificação de seus pontos fortes e fracos (tradução e adaptação nossa).

A Orientação é um elemento cujas características são análogas no PIBID e nos programas de indução à docência, bem como o processo de Mentoria que, no PIBID, se dá por meio da coordenação e do professor supervisor. O coordenador de área (professor da universidade) e o professor supervisor da escola parceira, com experiências distintas, pertencentes a instituições de ensino diferentes, permitem maior variedade de conhecimentos a serem mobilizados durante a orientação dos bolsistas de iniciação à docência. Ambos os elementos se organizam de forma bastante similar nesses programas.

Por sua vez, o Ajuste nas condições de trabalho, Redução de carga didática e Desenvolvimento Profissional são elementos melhor caracterizados nos programas de indução à docência, visto que os licenciandos não assumem carga didática e não são profissionais em situação de trabalho formal. Entretanto, ações de formação e adequação da carga de trabalho (quantidade de intervenções e turmas acompanhadas) são permanentes dentro dos subprojetos do PIBID.

A Colaboração com os pares no PIBID propicia que a sensação de isolamento tenda a ser menor que a do professor iniciante, uma vez que as reuniões e as trocas de experiências entre os licenciandos, coordenador de subprojeto e supervisor são constantes. Os trabalhos colaborativos são frequentes e de longa duração, o que pode possibilitar a criação de vínculos mais consolidados entre os sujeitos envolvidos, permitindo maior amparo das angústias vivenciadas no processo de se tornar 
professor.

Por último, a Avaliação das práticas realizadas no âmbito do PIBID deve ser efetuada de forma constante. Todas as atividades na escola são acompanhadas de supervisão de um professor da educação básica e passam por avaliação coletiva incluindo o professor coordenador da universidade. Além disso, os licenciandos fazem relatórios periódicos para acompanhamento e avaliação das intervenções realizadas.

Assim sendo, podemos perceber que, apesar de não ser um programa específico para professores em início de carreira, o PIBID possui diversas características que atendem à preparação para essa fase da docência. Contudo, as mudanças no Programa, realizadas pela CAPES em 2018, implicam alterações nas suas características formativas.

O Edital CAPES n. 07/2018 trouxe mudanças importantes para a estrutura do PIBID em relação aos editais anteriores, mantendo inalterados, contudo, os objetivos do Programa em sua essência. Vamos analisar a seguir algumas destas mudanças.

Restrição na participação no PIBID aos discentes que estejam na primeira metade de curso de licenciatura. "[...] Considera-se discente na primeira metade do curso aquele que não tenha concluído mais de 60\% da carga horária regimental do curso" (CAPES, Edital n. 07/2018, item 2.3.1.1). Anteriormente, podiam participar do PIBID licenciandos em qualquer fase do curso de formação inicial docente, possibilitando a formação de grupos colaborativos heterogêneos. Vetada a participação de licenciandos que estão prestes a iniciar a carreira, é evidente que a preocupação e as angústias com a expectativa do início da docência sejam esvaziadas nas discussões dos grupos. Além disso, é menos provável encontrar licenciandos que já estejam atuando como professores e que poderiam exercer em seus grupos a função de parceiros mais capazes.

Restrição à participação de um componente curricular/curso em diferentes subprojetos. "Não poderá compor o subprojeto multidisciplinar curso que já tenha constando em subprojeto específico" (ibidem, item 8.6.2). No formato anterior, não havia essa restrição, possibilitando que uma mesma IES tivesse mais de um subprojeto multidisciplinar e também tivesse alunos de um mesmo curso participando de subprojetos disciplinares e de projetos multidisciplinares. Essa redução, na prática, impede o desenvolvimento de diferentes trabalhos dentro de uma área específica, o que reduz as alternativas de formação para atuação do futuro professor. Além disso, a restrição parece contraditória com um dos princípios da iniciação à docência expresso no próprio Edital, a saber, "valorização do trabalho coletivo e interdisciplinar" (ibidem, item 9.7.1).

Restrição das condições de desenvolvimento das atividades. O novo edital apresenta pelo menos três mudanças que afetam diretamente a qualidade das ações que se desenvolvem no Programa. São elas:

1. Aumento no número de bolsistas por supervisor/coordenador de área. Os subprojetos passaram a ser formados por núcleos de iniciação à docência que devem ser formados "por 1 coordenador de área, 3 supervisores e, no mínimo, 24 e, no máximo, 30 discentes" (ibidem, item 2.3.5). Anteriormente, os tutores podiam orientar um mínimo de cinco bolsistas. $\mathrm{O}$ aumento do número de licenciandos por supervisor e coordenador de área dificulta o trabalho de acompanhamento e tutoria no processo formativo dos bolsistas licenciandos. Essa dificuldade, somada à restrição de participação aos alunos de início de curso, leva a um processo de esvaziamento da atuação de sujeitos mais capazes na ZDP dos professores em formação;

2. Incentivo à participação de professores coordenadores e licenciandos sem bolsa nos subprojetos. "[..] Para completar o número de 30 discentes, a IES será incentivada a incluir participantes sem bolsa" (ibidem, item 5.3). O indicador do esforço institucional para inclusão sem bolsa de professores e alunos corresponde a 40\% dos pontos do Barema, enquanto os três outros indicadores têm metade do peso que esse indicador apresenta para a avaliação das propostas (ibidem, Anexo 1). A presença de participantes com e sem bolsa em um mesmo grupo pode gerar assimetrias no comprometimento e disponibilidade dos sujeitos e tem alto potencial de causar desarmonia nas relações pessoais entre eles;

3. Extinção da figura de coordenação de área de gestão de processos educacionais. Essa modalidade de bolsa não foi contemplada no Edital em questão, significando que o coordenador 
institucional não possui na equipe um membro para auxiliar na gestão do Programa. Essa mudança fatalmente implica um aumento da demanda de trabalho para o coordenador institucional.

Restrição ao tempo de participação no programa. "O discente não poderá receber bolsa por período superior a 18 meses" (ibidem 6.1.4), e o coordenador institucional, o coordenador de área e o supervisor "não poderão receber bolsa por período superior a 96 meses" (ibidem 6.6), considerandose, em todos os casos, a participação na mesma modalidade, em qualquer subprojeto ou edição do Programa. Essa restrição afeta principalmente os licenciandos que não podem desfrutar de tempo suficiente no programa para vivência de situações que poderiam, de fato, projetá-lo na carreira docente. O tempo de ambientação na escola varia para cada sujeito; mas, na condição de recém-egresso da educação básica, os dezoito meses dificilmente são suficientes para o 'aluno' se perceber em outro papel, para se projetar como 'docente’ e experienciar desse lugar as situações do magistério.

Essas e outras mudanças advindas do Edital CAPES n. 07/2018 formam um quadro que aponta para um novo sistema da atividade do PIBID. A Figura 6 incorpora parte das alterações no sistema.

Figura 6 - Alterações no Sistema de Atividade do PIBID

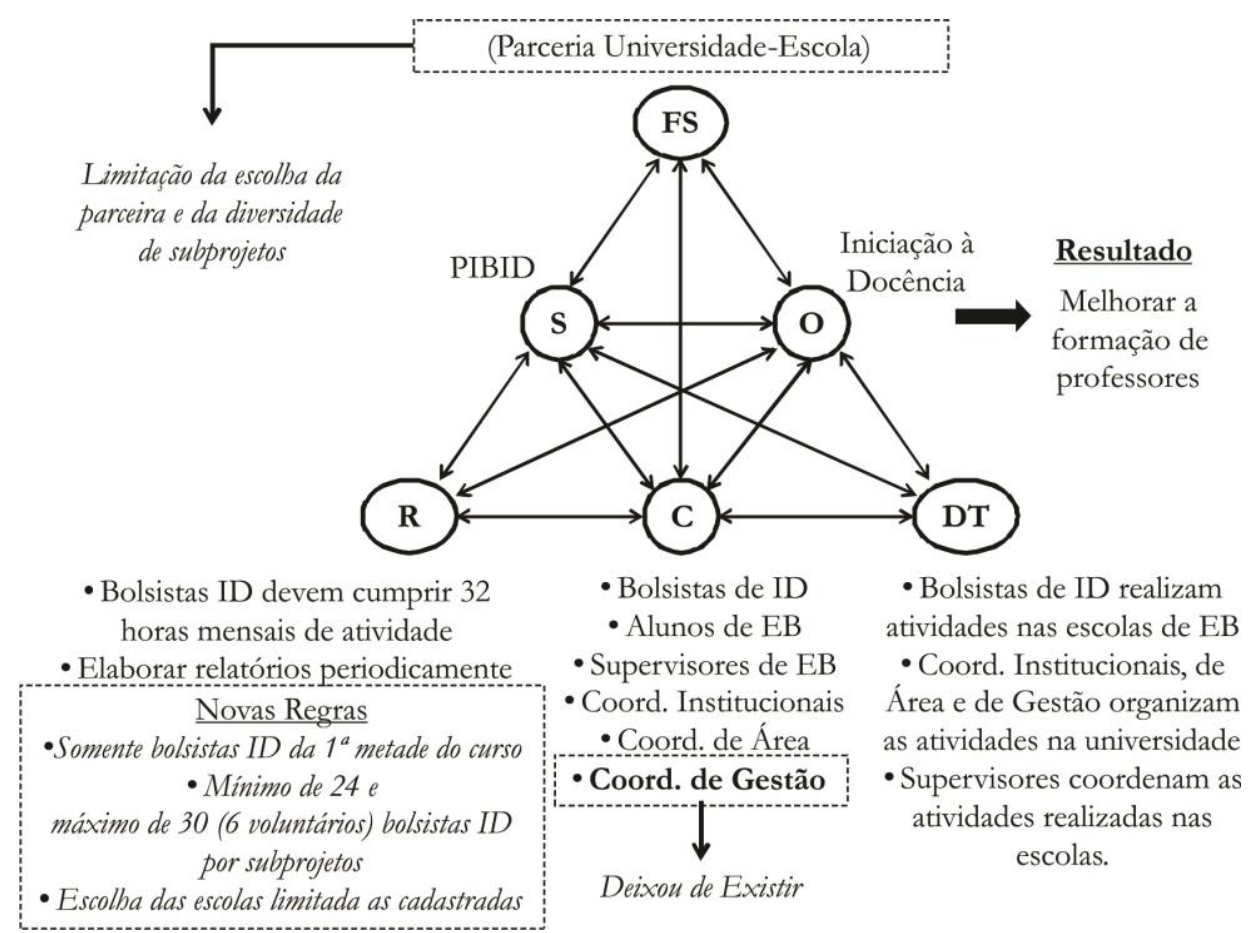

Fonte: elaborada pelos autores

As alterações realizadas no PIBID indicam que houve um aumento do número de regras, uma diminuição de cargos de gestão/coordenação e uma limitação na autonomia dos subprojetos. A participação das instituições de ensino (EB e IES) passa a ser precedida por etapas sobre as quais essas instituições não têm controle, o que limita a sua autonomia para o desenvolvimentos dos subprojetos, aumentando a burocratização da participação dessas Instituições junto ao Programa. A primeira etapa consiste na "formalização de Acordo de Cooperação Técnica (ACT) firmado entre a CAPES, o Conselho Nacional de Secretarias de Educação (Consed) e a União Nacional dos Dirigentes Municipais de Educação (Undime)" (ibidem, item 3.1). Posteriormente, os estados e municípios devem aderir ao ACT por meio de suas secretarias de educação ou órgãos equivalentes. Apenas após a adesão das secretarias de educação, as escolas podem manifestar interesse junto às primeiras para comporem a lista de escolas passíveis de escolha pelas IES. Assim, dificulta-se o estabelecimento de uma parceria universidade-escola pautada prioritariamente pelo potencial do professor da escola para assumir o compromisso de tutor dos 
futuros professores. Outros interesses podem pressionar o cadastro e a escolha das escolas, como a expansão territorial do Programa e o aumento de sua capilaridade nas escolas de educação básica.

Esses não são objetivos ilegítimos de uma política nacional, mas afastam o PIBID de sua proposição inicial, que é contribuir com o aprimoramento da preparação dos professores para que se iniciem na carreira docente - objetivo este que o Programa vinha cumprindo de forma satisfatória, como as análises de nível micro e meso e outras pesquisas revelaram (ANDRÉ, 2012; GATTT et al., 2014).

Portanto, ao considerar o PIBID como uma unidade de análise, percebemos que as mudanças determinadas pelo Edital CAPES n. 07/2018, que alteraram os elementos do seu sistema de atividade sem modificar o seu objeto, geram tensões entre os diferentes elementos de sua atividade. Tais tensões podem fazer emergir contradições nos diferentes níveis hierárquicos da cadeia do sistema de atividade do Programa, o que dificulta a realização das ações necessárias para alcançar os seus objetivos. Contudo, na prática, o que ocorre é que o objeto se modifica junto com as mudanças impostas, gerando um outro sistema de atividade do PIBID, o que exige repensar o seu papel na formação inicial de professores.

\section{CONCLUSÕES}

Neste trabalho, realizamos uma análise em três níveis (micro, meso e macro) sobre os aportes fornecidos pelo PIBID na preparação de licenciandos para o início da docência. No nível micro, focalizamos como as atividades realizadas pelos bolsistas de um Subprojeto de Física ajudaram a preparálos para o enfrentamento futuro dos desafios do início da docência. No nível meso, analisamos quais características e ações desse Subprojeto mais contribuíram e quais se mostraram limitadas para a preparação dos licenciandos para o início na profissão. No nível macro, refletimos sobre como as mudanças no PIBID, impostas pelo Edital CAPES n. 7/2018, podem impactar a preparação dos licenciandos para o início da docência.

A análise de nível micro revelou que as atividades do PIBID possibilitaram aos bolsistas vivência amparada de diversos momentos de contradições que impulsionam o desenvolvimento profissional docente. Já a análise meso evidenciou que, entre as características do subprojeto analisado que mais favoreceram a preparação dos licenciandos para o início da carreira docente, se destacam a heterogeneidade do grupo e as trocas entre os pares, que possibilitaram a construção de novos conhecimentos sobre a docência, pela atuação dentro da ZDP de cada bolsista. Esse nível da análise também revelou algumas limitações no Programa, como a interação com um grupo restrito de sujeitos, dentre aqueles que compõem o sistema de atividade de um professor de educação básica. Por fim, a análise em nível macro evidenciou que as mudanças impostas ao PIBID incidem sobre aspectos fundamentais do Programa, como na escolha da escola, na constituição dos grupos de trabalho, no trabalho de tutoria e acompanhamento dos bolsistas.

Consideramos que estes e outros fatores podem afetar negativamente a preparação dos futuros professores para iniciarem a carreira docente, pois, embora os objetivos do PIBID não tenham sido em essência alterados no documento oficial (Edital CAPES n.7/2018), na prática há uma descaracterização do Programa e uma nova orientação que aponta para o aumento da capilaridade do Programa em detrimento da qualidade do aporte para a formação de novos professores.

Essas mudanças no PIBID colocam-nos diante de mais uma descontinuidade das políticas públicas no Brasil, fato comum em países da América Latina, que dificulta o planejamento e a execução de ações educacionais de longo prazo, o que afeta negativamente a melhoria da educação nesses países. E, nesse sentido, não só o PIBID é afetado, mas todos os cursos de formação de professores que tinham práticas consolidadas para desenvolvimento dos estágios supervisionados em parcerias com escolas de educação básica.

Portanto, entendemos que existe a necessidade de continuidade da investigação sobre o PIBID, focalizando sua articulação com outros programas, dentro do contexto das políticas públicas brasileiras para a formação de professores.

Em especial, acreditamos que elementos relevantes podem advir da análise do PIBID em articulação com o Programa de Residência Pedagógica (PRP), divulgado por meio do Edital CAPES 
n.6/2018, lançado simultaneamente com o Edital CAPES n. 7/2018. O PRP foi desenhado de forma muito similar ao PIBID, mas com a possibilidade de validação de cumprimento de horas de estágio curricular obrigatório e, portanto, restrito aos licenciandos que estejam na segunda metade de seus cursos, em momento mais próximo da entrada na profissão.

Se considerarmos os dois Programas como sistemas de atividades dentro de um sistema de nível hierárquico superior que represente políticas para a formação de professores, por exemplo, poderemos entender o PIBID e o PRP como ações desse sistema principal e desvelar as contradições que podem emergir da manutenção de duas ações com objetos idênticos e regras diferenciadas.

Além disso, cabe-nos concluir que o País ainda carece de um programa que seja direcionado aos professores principiantes, com acompanhamento e apoio após o término do curso de formação inicial, objetivando a indução ao início da carreira, como em diversos programas já existentes pelo mundo.

Dessa forma, teríamos um programa que possibilitaria à IES formadora acompanhar o professor nos primeiros anos da docência, momento em que ele já estaria vivendo toda a complexidade da atividade docente na educação básica, em suas relações com todas as regras, instrumentos, sujeitos da comunidade etc. Seria um avanço real nas políticas para formação de professores no País, uma vez que se poderia definir uma perspectiva mais clara para o futuro professor em termos de formação inicial e atuação no início da carreira docente. Quiçá isso possa contribuir para atenuar os problemas referentes ao déficit de professores no País e impactar positivamente na qualidade da formação do estudante na educação básica.

\section{AGRADECIMENTOS}

Agradecemos o apoio do CNPq, ao qual este trabalho está vinculado por meio do Projeto Universal n. 434918/2018-0. Também agradecemos o apoio da CAPES - Código de Financiamento 001, na etapa de coleta de dados da pesquisa.

\section{REFERÊNCIAS}

ANDRÉ, M. Políticas e Programas de apoio aos professores iniciantes no Brasil. Cadernos de Pesquisa, São Paulo, v.42, n.145, p.112-129, jan./abr. 2012.

ARAUJO, E. S.; MORAES, S. G. Dos princípios da pesquisa em educação como atividade. In: MOURA, M. O. (org.). Educação Escolar e Pesquisa na teoria Histórico-Cultural. São Paulo: Edições Loyola, v.1, p. 47-70, 2017.

BRASIL. Instituto Nacional de Estudos e Pesquisas Educacionais Anísio Teixeira (Inep). Censo da Educação Básica 2019. Resumo Técnico. Brasília, 2020.

CAMILLO, J.; MATTTOS, C. Educação em Ciências e a Teoria da Atividade Cultural-Histórica: contribuições para a reflexão sobre tensões na prática educativa. Ensaio: Pesquisa Em Educação Em Ciências, v. 16, n. 1, p. 211-230, 2014.

CAPES. Coordenação de Aperfeiçoamento de Pessoal de Nível Superior. Programa Institucional de Bolsa de Iniciação à Docência - PIBID. Chamada pública para apresentação de propostas edital $n^{\circ}$ 7/2018. Brasília, Brasil, 2018.

COLOMBO, P. D. J. Professor no início da carreira: crenças e conflitos. In: Encontro Nacional de Pesquisa em Ensino de Física, 7, 2009, Florianópolis. Atas... Florianópolis: SBF, 2009.

DANIELS, H. Vygotsky e a pesquisa. São Paulo: Edições Loyola, 2011. 
DIAS, V. S.; RABELO, L. O. A manutenção dos professores na carreira docente no Brasil: analisando o papel da tutoria no Programa Institucional de Bolsa de Iniciação à Docência (PIBID). Enseñanza de las Ciencias, v. 1, p. 3001-3005, 2017.

ENGESTRÖM, Y. Learning by expanding: An activity-theoretical approach to developmental research. Helsinki: Orienta-Konsultit, 1987.

ENGESTRÖM, Y. Expansive Learning at Work: toward an activity theoretical reconceptualization. Journal of Education and Work, v. 14, n. 1, p. 133-156, 2001.

ENGESTRÖM, Y.; SANNINO, A. Studies of expansive learning: Foundations, findings and future challenges. Educational Research Review, v. 5, p. 1-24, 2010.

EUROPEAN COMMISSIAN/EACEA/EURYDICE. The European Higher Education Area in 2015: Bologna Process Implementation Report. Luxembourg: Publications Office of the European Union, 2015.

GATTI, B.; ANDRÉ, M. E. D. A.; GIMENES, N. A. S.; FERRAGUT, L. Um estudo avaliativo do Programa Institucional de Bolsa de Iniciação à Docência (Pibid). São Paulo: Fundação Carlos Chagas, v. 41, set. 2014.

GOLDRICK, L.; OSTA, D.; BARLIN, D.; BURN, J. Review of state policies on teacher induction. Santa Cruz, CA: New Teacher Center, 2012.

HUBERMAN, M. O ciclo de vida dos professores. In: NÓVOA, A. (org.). Vidas de professores. Porto: Porto Editora, p. 31-61, 1995.

IBAÑEZ R. A.; RAMOS, M. N.; HINGEL, M. Escassez de Professores no Ensino Médio: propostas estruturais e emergenciais. Brasília: MEC/CNE/CEB, 2007.

JENSEN, B., SANDOVAL-HERNÁNDEZ, A., KNOLL, S.; GONZALEZ, E. J. The experience of new teachers: results from TALIS 2008. OECD Publishing, 2012.

KUSSUDA, S. R. A escolha profissional de licenciados em física de uma universidade pública. 184 f. Dissertação (Mestrado em Educação para a Ciência). Faculdade de Ciências. Universidade Estadual Paulista Júlio de Mesquita Filho, Bauru, 2012.

LEONTIEV, A. N. O desenvolvimento do psiquismo. 2 ed. São Paulo: Centauro Editora, 2004.

LEONTIEV, A. N. Uma contribuição à teoria do desenvolvimento da psique infantil. In: Vigotskii, L. S.; Luria, A. R.; Leontiev, A. N. Linguagem, desenvolvimento e aprendizagem. 11 ed. São Paulo: Ícone, p. 59-83, 2010.

LIMA, E. F.; Corsi A. M.; MARIANO, A. L. S.; MONTEIRO, H. M.; PIZZO, S. V.; ROCHA, G. A.; SILVEIRA, M. F. L. Sobrevivendo ao início da carreira docente e permanecendo nela. Como? Por quê? O que dizem alguns estudos. Educação e Linguagem, n.15, p. 138-160, jan./jun. 2007.

MARCELO GARCÍA, C. Aprender a enseñar: Um estúdio sobre el processo de socialización de profesores principiantes. Madrid, Centro de Publicaciones del Ministerio de Educación y Ciencia: C.I.D.E., 1991. 
MARCELO GARCÍA, C. Políticas de inserción a la docencia: del eslabón perdido al puente para el desarrollo profesional docente. In: Taller Internacional Las políticas de inserción de los nuevos maestros en la profesión docente: la experiencia latinoamericana y el caso colombiano. Atas... Bogotá, nov. 2006.

MARCELO GARCÍA, C.; VAILLANT, D. Políticas y programas de inducción en la docencia en Latino América. Cadernos de Pesquisa, v. 47, n. 166, p. 1224-1249, 2017.

MATTOS, C. Livro didático na atividade educacional: a parte ou o todo?. In: GARCIA, N. M. D.; AUTH, M. A.; TAKAHASHI, E. K. (org.). Enfrentamentos do ensino de física na sociedade contemporânea São Paulo: LF Editorial, 2016, pp. 103-120.

OCDE. Organização para a Cooperação e Desenvolvimento Econômico. Professores são

importantes: atraindo, desenvolvendo e retendo professores eficazes. São Paulo: Moderna, 2006.

PINTO, M. R. O que explica a falta de professores nas escolas brasileiras. Jornal de Políticas Educacionais, n. 15, p. 03-12, jan./jun. 2014.

RABELO, L. O.; HANITA, M. Y. Os trabalhos sobre o PIBID no Congresso Internacional sobre Professor Principiante e Inserção Profissional à Docência. Revista de Iniciação à Docência, v. 3, n. 1, p. 22-31, 2018.

RABELO, L O.; DIAS, V. S. Programas de iniciação à docência: situando o caso do PIBID no Brasil. In: GALIAN, C. V. A.; ZUFF, E. M.; PIETRI, E. (Org.) . A formação de professores sob novos ângulos: o PIBID na Universidade de São Paulo (2015-2018). 1. ed. São Paulo: FEUSP, 2019. pp. 516.

SÁNCHEZ, N. H. M. (org). Alzando el vuelo: problemas y modelos de acompañamiento al docente novel. México, Monterrey: Fundo Editorial de Nuevo León, 2012, p. 176.

SOUSA, W. D. D.; LONGAREZI, A. M. . Imitação-criação no processo de formação para o desenvolvimento profissional docente. Práxis educativa (impresso) , v. 13, p. 443-462, 2018.

TARDIF, M. Saberes profissionais dos professores e conhecimentos universitários: elementos para uma epistemologia da prática profissional dos professores e suas consequências em relação à formação para o magistério. Revista Brasileira de Educação, Rio de Janeiro, n. 13, jan./fev./mar./abr., p. 5-24, 2000 .

TURNER, J. H. Human Emotions: A sociological theory. London and New York: Routledge Taylor \& Francis Group, 2007.

UNESCO, Teaching and learning: achieving quality for all; EFA Global monitoring report, 20132014, Global Education Monitoring report Team, 2014.

UNESCO, International Yearbook of Education, Vol. XXIV, International Bureau of Education, Geneva, 1962.

VAILLANT, D. Políticas de inserção a la docência en América: la deuda pendiente. Latin. Revista de Currículum y Formación de Profesorado, Granada/Espanha, v. 13, n. 1, p. 27-41, abr. 2009.

VIGOTSKI, L. S. Construção do pensamento e da linguagem. São Paulo: Martins Fontes, 2001. 
VIGOTSKI, L. S. Imaginação e criação na infância. Trad. Zoia Prestes. São Paulo: Ática, 2009.

Submetido: $18 / 11 / 2019$

Aprovado: 15/09/2020 